Jiahui Xia $\cdot$ Hao Deng $\cdot$ Yong Feng $\cdot$ Huali Zhang

Qian Pan · Heping Dai · Zhigao Long • Beisha Tang

Hanxiang Deng • Yong Chen • Ruifang Zhang

Duo Zheng • Yungui He $\cdot$ Kun Xia

\title{
A novel locus for autosomal dominant nonsyndromic hearing loss identified at 5q31.1-32 in a Chinese pedigree
}

Received: May 8, 2002 / Accepted: October 1, 2002

\begin{abstract}
Hearing impairment is an extremely heterogeneous disorder. A total of 35 loci and 17 related genes for autosomal dominant nonsyndromic hearing loss have been identified. In a Chinese pedigree characterized by autosomal dominant inheritance with bilateral, postlingual, progressive, and sensorineural nonsyndromic hearing impairment, the putative disease gene locus was localized to chromosome 5q31.1-32 by a genome-wide scan. Fine mapping indicated that the disease gene was located within an 8.8-cM region between markers D5S2056 and D5S638, with a maximum two-point logarithm of differences (LOD) score of $6.89(\theta=0)$ at $D 5 S 2017$. By the candidate gene approach, mutation screening of the DIAPH1 and $P O U 4 F 3$ genes at $5 \mathrm{q} 31$ was performed. No mutation was found, suggesting that this is a novel deafness locus, which has been named DFNA42.
\end{abstract}

Key words Autosomal dominant nonsyndromic hearing loss · Linkage analysis - Logarithm of differences (LOD) score $\cdot$ DFNA42 $\cdot$ Heterogeneous disorder

\section{Introduction}

Hearing impairment is an extremely heterogeneous disorder that affects about 1 in 2000 newborns. Hereditary hearing loss can be classified as syndromic (SHL) or nonsyndromic (NSHL). Nonsyndromic hearing loss is a common sensory deafness and can be divided into two types: prelingual and postlingual deafness. Within the prelingual NSHL category, $75 \%-80 \%$ are autosomal reces-

J. Xia $\cdot$ H. Deng $\cdot$ H. Zhang $\cdot$ Q. Pan $\cdot$ H. Dai $\cdot$ Z. Long $\cdot$ B. Tang $\cdot$ H.X. Deng $\cdot$ Y. Chen $\cdot$ R. Zhang $\cdot$ D. Zheng $\cdot$ Y. He $\cdot$ K. Xia $(\bowtie)$ The State Key Laboratory of Medical Genetics, Central South University, 88 Xiangya Road, Changsha, Hunan 410078, P.R. China Tel. +86-731-4472093; Fax +86-731-4478152

e-mail:nlmglcy@xymu.net

Y. Feng

Department of Otorhinology, the Affiliated Xiangya Hospital,

Central South University, Changsha, Hunan, P.R. China sive, $20 \%-25 \%$ are dominant, and $1 \%-1.5 \%$ are $\mathrm{X}$-linked. In nearly all hereditary postlingual NSHL families, inheritance patterns are autosomal dominant.

To date, 71 NSHL loci have been reported, including 35 autosomal dominant, 29 recessive, 5 X-linked, and 2 mitochondrial loci. Among them, 28 related genes for NSHL have been identified. A total of 17 genes for autosomal dominant NSHL have been isolated, including GJB2 (Kelsell et al. 1997), GJB3 (Xia et al. 1998), GJB6 (Grifa et al. 1999), COCH (Robertson et al. 1998), COL11A2 (McGuirt et al. 1999), DFNA5 (Van Laer et al. 1998), DIAPH1 (Lynch et al. 1997), KCNQ4 (Kubisch et al. 1999), MYO7A (Liu et al. 1997), POU4F3 (Vahava et al. 1998), TECTA (Verhoeven et al. 1998), MYH9 (Lalwani et al. 2000), EYA4 (Wayne et al. 2001), MYO6 (Melchionda et al. 1998), DSPP (Xiao et al. 2001), WFS1 (Bespalova et al. 2001; Young et al. 2001), and TMC1 (Kurima et al. 2002). These genes perform a wide range of functions, such as intercellular communication via gap-junction formation, regulation of actin polymerization by $D I A P H 1$, transcription regulation by $P O U 4 F 3$, tectorial membrane integrity, and anchoring of the actin cytoskeleton by mysin, thus suggesting that many different processes are involved in auditory functioning and development. Identification of different NSHL disease-causing genes will help to elucidate the molecular basis of hearing and hearing loss.

The Chinese kindred presented here displays autosomal dominant, bilateral, postlingual, progressive and sensorineural hearing loss. We report here the results of a linkage analysis and mutation detection of this family that revealed a novel locus for DFNA, which we have named DFNA42.

\section{Subjects and methods}

Family

A Chinese family with hearing impairment was identified by the Department of Otorhinolaryngology of the Xiangya Hospital of Central South University. Written informed 
consent was obtained from all study participants. All subjects, recruited from Hunan Province, China, underwent pure-tone audiometry (PTA) and distortion product otoacoustic emission (DPOAE) testing, and a complete physical examination. Pure-tone thresholds were determined with air conduction at $125-8000 \mathrm{~Hz}$ and bone conduction at $250-8000 \mathrm{~Hz}$. The criterion used to determine whether an individual was affected was bilateral sensorineural hearing loss of more than $30 \mathrm{~dB}$ at at least one frequency. Some patients underwent computerized tomography (CT) and vestibular testing. Previous audiological tests were collected if available.

\section{Allelotyping}

Blood samples were collected from 37 pedigree members. Genomic DNA was extracted from peripheral blood by standard phenol extraction protocols. Samples were quantified by spectrophotometry and diluted to $30 \mathrm{ng} / \mu \mathrm{L}$ for polymerase chain reaction (PCR) amplificaton. Genome-wide screening was performed with 382 markers spaced an average of $10 \mathrm{cM}$ apart (ABI PRISM Linkage Mapping Set, Version 2.0, Foster City, CA, USA). Fine mapping was accomplished using fluorescently labeled primers from the Généthon linkage map (Dib et al. 1996). Multiplex PCR was carried out in a $5 \mu$ l reaction mixture containing $30 \mathrm{ng}$ of genomic DNA, $1 \times$ PCR buffer, $200 \mu \mathrm{M}$ of each dNTP, $3.0 \mathrm{mM} \mathrm{MgCl}, 80 \mathrm{pmol}$ each of forward and reverse primers, and $0.2 \mathrm{U}$ of Ampli Taq Gold DNA polymerase. Reaction products were loaded onto a $6 \%$ denaturing polyacrylamide gel (7M urea) and visualized on an ABI 377XL sequencer. Alleles were analyzed by Genescan analysis version 3.0 software and Genotyper version 2.1 software.
Linkage analysis

A two-point linkage analysis was conducted using the MLINK program of the Linkage 5.1 package (Lathrop and Lalouel 1984). The disease allele frequency was set at 0.0001 , with the recombination fraction $(\theta)$ in men and women being considered equal. The disease was assumed to be fully penetrant and autosomal dominant on the basis of the pedigree information. The most likely haplotype was constructed by the Cyrillic program.

\section{Mutation analysis}

Primers were designed to amplify all exons and flanking intronic splicing sites of the DIAPH1 and POU4F3 genes. PCR was carried out in standard reaction mixtures, and amplified fragments were bidirectionally sequenced using an ABI 377XL sequencer.

\section{Results}

\section{Clinical data}

Thirty-seven members of the family were included in the study, of which 14 were affected; the earliest age of onset was 24 years old (V-9). Additionally, the PTA showed highfrequency hearing loss of $25 \mathrm{~dB}$ at $6000-8000 \mathrm{~Hz}$ in two other family members (IV-10, age 22; V-6, age 23), leading us to assume that they were possibly affected. No patients showed malformations of the inner ear by CT examination or abnormal function by vestibular testing. The characteristics of hearing loss in this pedigree was consistent with bilateral, postlingual, progressive, and sensorineural

Table 1. Two-point logarithm of differences (LOD) scores between the disease and chromosome $5 \mathrm{q}$ markers

\begin{tabular}{|c|c|c|c|c|c|c|c|c|}
\hline \multirow[b]{2}{*}{ Marker } & \multicolumn{7}{|c|}{ LOD score at $\theta={ }^{a}$} & \multirow[b]{2}{*}{$\mathrm{Z}_{\max }^{\mathrm{b}}$} \\
\hline & .0 & .01 & .05 & .10 & .20 & .30 & .40 & \\
\hline D5S1984 & - & -.54 & 1.20 & 1.64 & 1.56 & 1.04 & .41 & 1.70 \\
\hline D5S2002 & - & 1.64 & 2.64 & 2.74 & 2.25 & 1.42 & .44 & 2.75 \\
\hline D5S2117 & - & .92 & 2.00 & 2.19 & 1.90 & 1.28 & .51 & 2.19 \\
\hline D5S2056 & 1.42 & 3.48 & 3.77 & 3.54 & 2.70 & 1.65 & .57 & 3.77 \\
\hline D5S2115 & 3.08 & 3.09 & 3.01 & 2.80 & 2.21 & 1.48 & .68 & 3.09 \\
\hline D5S1983 & 4.56 & 4.48 & 4.14 & 3.71 & 2.80 & 1.84 & .88 & 4.56 \\
\hline D5S2116 & 6.05 & 5.95 & 5.51 & 4.95 & 3.73 & 2.40 & 1.00 & 6.05 \\
\hline D5S658 & 4.08 & 4.01 & 3.72 & 3.30 & 2.34 & 1.32 & .48 & 4.08 \\
\hline D5S2017 & 6.89 & 6.77 & 6.27 & 5.61 & 4.19 & 2.64 & 1.04 & 6.89 \\
\hline D5S643 & 1.54 & 1.54 & 1.51 & 1.40 & 1.07 & .66 & .24 & 1.54 \\
\hline D5S638 & 5.45 & 5.35 & 4.95 & 4.44 & 3.33 & 2.13 & .87 & 5.45 \\
\hline D5S436 & 3.62 & 3.55 & 3.27 & 2.91 & 2.15 & 1.37 & .61 & 3.62 \\
\hline D5S2033 & - & 1.80 & 2.30 & 2.30 & 1.86 & 1.19 & .46 & 2.33 \\
\hline D5S2090 & 4.62 & 4.59 & 4.37 & 4.00 & 3.10 & 2.03 & .89 & 4.62 \\
\hline D5S636 & - & .85 & 2.52 & 2.85 & 2.53 & 1.74 & .77 & 2.86 \\
\hline D5S640 & - & 1.46 & 2.67 & 2.89 & 2.50 & 1.70 & .73 & 2.89 \\
\hline D5S410 & - & -.82 & .35 & .67 & .68 & .44 & .17 & .68 \\
\hline
\end{tabular}

${ }^{a}$ LOD scores were calculated under an autosomal dominant mode of inheritance, with a penetrance of $100 \%$. IV-10 and V-6 were calculated as possibly affected and III- 6 as normal

${ }^{\mathrm{b}} \mathrm{Z}_{\max }$ was calculated using the ILINK program of the Linkage 5.1 package 


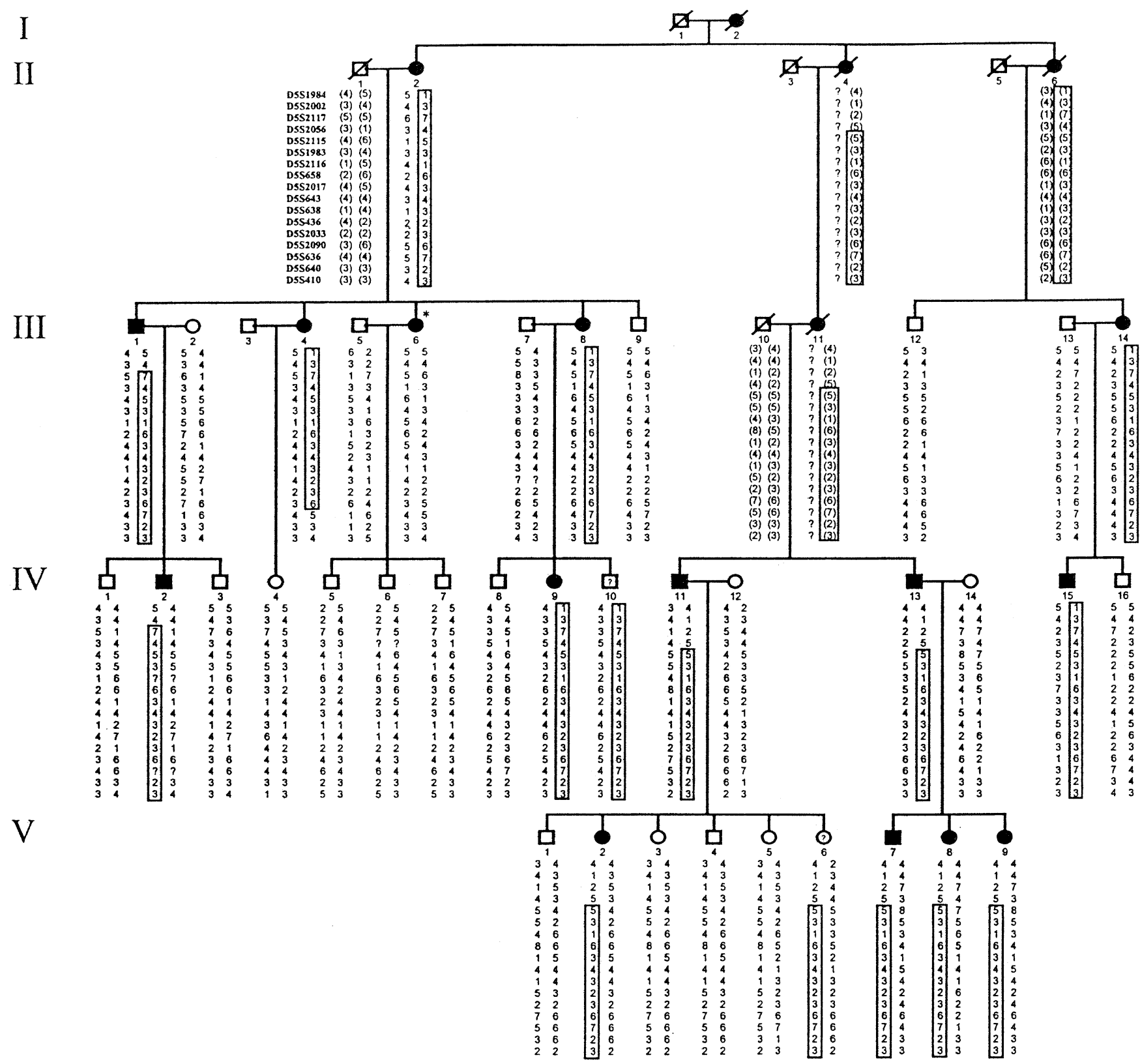

Fig. 1. Haplotype analysis of Chinese Hunan nonsyndromic hearing loss (NSHL) pedigree illustrating recombination events between the disease locus and chromosome 5q markers. Seventeen markers from chromosome 5 are shown at the upper left. The haplotype linked to

nonsyndromic hearing impairment. Examination of the history and clinical records of affected members suggested that high-frequency loss in this pedigree begins at the second or third decade and progresses to profound deafness involving all frequencies.

Two-point logarithm of differences scores

A maximum two-point logarithm of differences (LOD) score of 3.62 with marker D5S436 $(\theta=0)$ was obtained. Two markers flanking D5S436, D5S410 and D5S2115 produced maximum LOD scores of $0.68(\theta=0.2)$ and $3.08(\theta=$ deafness is boxed. Inferred alleles are in parentheses. A question mark (?) in circles or squares indicates possibly affected (IV-10, V-6). An asterisk $(*)$ indicates a member with a phenocopy (III-6)

$0)$. Fourteen additional markers around D5S2115 were selected from the Généthon linkage map for fine mapping. A maximum two-point LOD score of $6.89(\theta=0)$ was obtained at D5S2017. Combined pairwise LOD scores between relevant markers and the disease locus are given in Table 1.

Haplotype analysis

The most likely haplotype in our pedigree was constructed using the Cyrillic program (Fig. 1). In most affected family members, a linked haplotype was found. In the inferred 
Fig. 2. Map of chromosome $5 \mathrm{q}$ containing DFNA1, DFNA15, and candidate regions for the Chinese Hunan deafness pedigree. Genetic distances between the markers are from the Généthon linkage map. The links between the genetic and cytogenetic maps are inferred from the genome database report

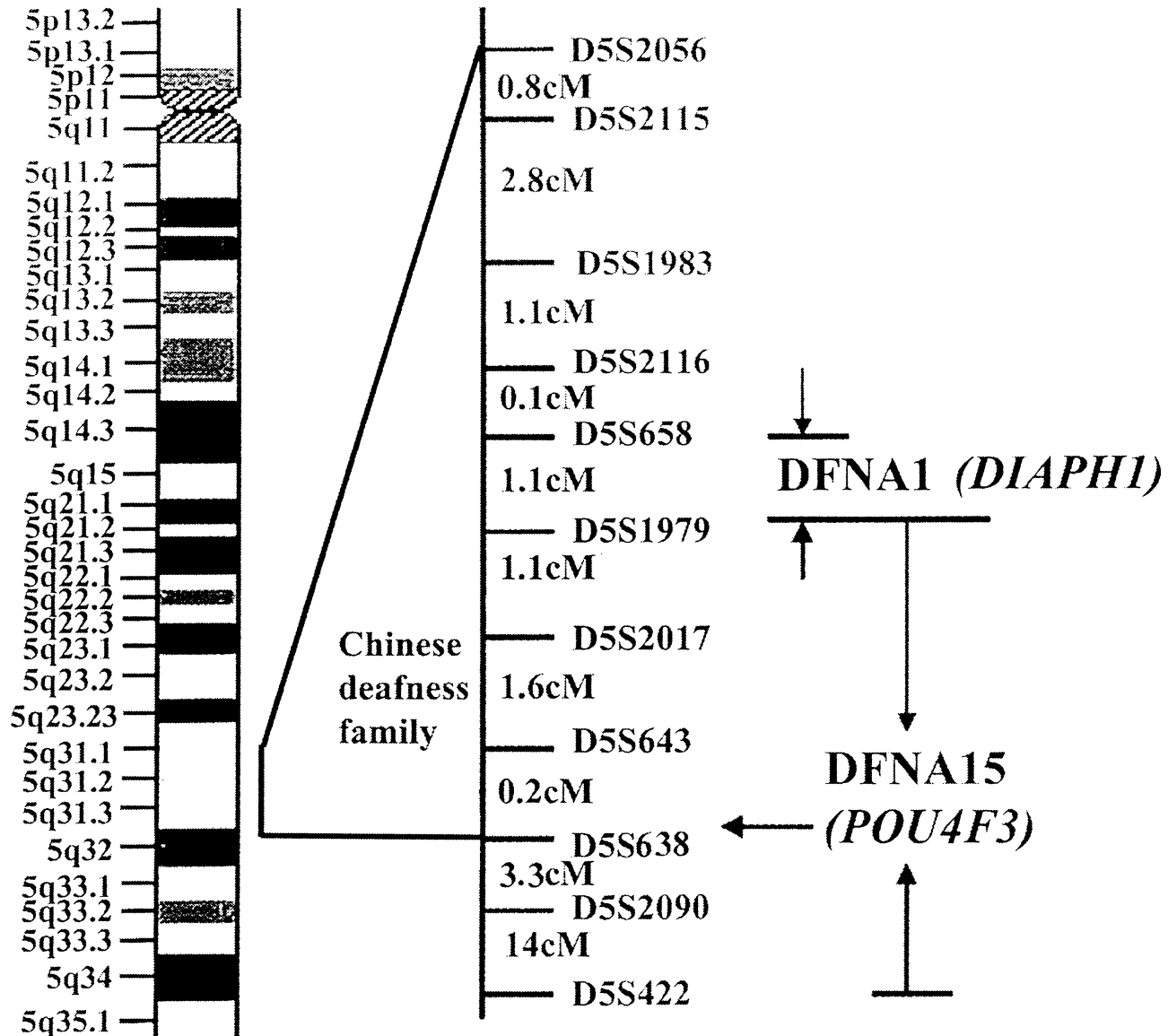

Discussion

haplotype of individual II-4, a recombination was present between D5S2056 and D5S2115, mapping the disease gene centromeric to marker D5S2056. Her affected descendents III-11, IV-11, and IV-13 have inherited this recombinant chromosome. Another important recombination event was present between D5S643 and D5S638 in a single unaffected individual (IV-8). He is 42 years old with a normal PTA. Because his mother is homozygous at D5S643, it is not known whether the recombination event occurred between D5S2017 and D5S643 or between D5S643 and D5S638. Thus, we estimate that the interval is $8.8 \mathrm{cM}$, flanked by D5S2056 and D5S638 at 5q31.1-q32.

Mutation analysis

Two genes, DIAPH1 and POU4F3 for DFNA1 and DFNA15, respectively, have been localized to 5q31 (Fig. 2). We analyzed these two genes by direct sequencing. The amplified DNA fragments containing the exons and flanking intronic splicing sites of DIAPH1 and POU4F3 were gel-purified and sequenced. No mutation was found in this family.
In this study, we identified DNFA42 at chromosome 5q31.1q32 in a Chinese NSHL family. Thirteen affected members have inherited the disease haplotype; only one affected woman (Fig. 1, III-6) does not carry the haplotype linked to deafness. As the woman is 60 years old and has three children who are normal in hearing, her hearing impairment may be a phenocopy caused by nongenetic factors such as aging. Two individuals, IV-10 and V-6, were confirmed to carry the deafness-linked haplotype, having a hearing loss of $25 \mathrm{~dB}$ only at $6000-8000 \mathrm{~Hz}$. We considered them as possibly affected individuals because both of them were less than 24 years old.

Two other loci, DFNA1 (Leon et al. 1992) and DFNA15 (Vahava et al. 1998), have been localized to 5q31. DFNA1 causes a type of nonsyndromic, dominant, postlingual progressive hearing loss, and is caused by mutations in the human homolog of the Drosophila gene diapharous (DIAPH1) (Lynch et al. 1997). DIAPH1 is one member of the formin gene family, involved in cytokinesis and the establishment of cell polarity. DIAPH1 is located in the candidate region that we identified (Fig. 2), but no mutation of the DIAPH1 gene was found in this family. The affected individuals in this family show a high-frequency hearing impairment onset at 24 years old, whereas DFNA1 is characterized by the onset of low-frequency hearing loss at 10 
years of age, progressing to profound bilateral deafness involving all frequencies by the age of 30 . Therefore, $D I A P H 1$ can be excluded as a candidate for deafness in this family.

DFNA15 is another locus mapped to $5 \mathrm{q} 31$, in which hearing loss begins between ages 13 and 30 years, with moderate to severe defects in hearing occurring by age 50 years. Mutations in POU4F3 have been reported to be associated with DFNA15 (Vahava et al. 1998). The locus for DFNA15 overlaps with the candidate region of this family (Fig. 2), and POU4F3 is localized closely to D5S436; however, it is not within the critical region of this NSHL locus. $P O U 4 F 3$ was also analyzed for mutations, but no mutation was found. Thus, the locus for this deafness pedigree is probably a novel locus, and we named it DFNA42.

To determine the gene responsible for hearing impairment in this family, a database search was performed (www.genome.ucsc.edu). In the region 5q31.1-q32, there are a number of genes that are expressed in the developing human inner ear: the early growth response 1 gene (EGRI), the human homolog of the Drosophila gene diaphanous (DIAPH1), the pou-domain transcription factor brn3c gene (POU4F3), antiquitin (ATQ1), the protein phosphatase 2A catalytic subunit gene (PPP2CA), and the osteonectin gene $(S P A R C)$. There are also a number of genes mapped to this region that are expressed in the developing inner ear of nonhuman vertebrates: genes for glucocorticoid receptor $(G C R)$, bumetanide-sensitive Na-K-CL cotransporter (SLC12A2), neurogenin 1 (NEUROD3), integrin alpha-2 (ITGA2), catenin alpha-1 (CTNNA1), and fibroblast growth factor $1(F G F 1)$. Of the above genes, CTNNA1 is a good candidate for DFNA42, because E-cadherin-mediated cellcell adhesion is affected by three cytoplasmic proteins known as alpha, beta, and gamma catenins. These catenins are thought to function as connectors that anchor Ecadherin to the cytoskeletal actin bundle through the cadherin cytoplasmic domain. The cadherin 23 gene (CDH23) has been confirmed to be the cause of type 1D Usher syndrome and DFNB12 (Bolz et al. 2001; Bork et al. 2001).

It has been reported that mouse $\operatorname{slc12a2}$ is related to deafness and inner-ear defects (Delpire et al. 1999), but human SLC12A2 was excluded as it is located centromerely to D5S2078, which is $3.4 \mathrm{cM}$ away from the DNFA42 locus. Mutation analysis of the gene responsible for DNFA42 is underway.

Acknowledgments This study was supported by grants from the "973" and "863" programs, the National Natural Science Foundation of China (39896200, 39980018, 39980040, 30100103), the Special Foundation for Doctoral Degree Dissertation of the Ministry of Education (200014), and the National Prominent Youth Foundation (39525012) of China.

\section{References}

Bespalova IN, Van Camp G, Bom SJ, Brown DJ, Cryns K, DeWan AT, Erson AE, Flothmann K, Kunst HP, Kurnool P, Sivakumaran TA, Cremers CW, Leal SM, Burmeister M, Lesperance MM (2001) Mu- tations in the Wolfram syndrome 1 gene (WFS1) are a common cause of low frequency sensorineural hearing loss. Hum Mol Genet 10:2501-2508

Bolz H, von Brederlow B, Ramirez A, Bryda EC, Kutsche K, Nothwang HG, Seeliger M, del C-Salcedo Cabrera M, Vila MC, Molina OP, Gal A, Kubisch C (2001) Mutation of $C D H 23$, encoding a new member of the cadherin gene family, causes Usher syndrome type 1D. Nat Genet 27:108-112

Bork JM, Peters LM, Riazuddin S, Bernstein SL, Ahmed ZM, Ness SL, Polomeno R, Ramesh A, Schloss M, Srisailpathy CR, Wayne S, Bellman S, Desmukh D, Ahmed Z, Khan SN, Kaloustian VM, Li XC, Lalwani A, Riazuddin S, Bitner-Glindzicz M, Nance WE, Liu XZ, Wistow G, Smith RJ, Griffith AJ, Wilcox ER, Friedman TB, Morell RJ (2001) Usher syndrome 1D and nonsyndromic autosomal recessive deafness DFNB12 are caused by allelic mutations of the novel cadherin-like gene $C D H 23$. Am J Genet 68:26-37

Delpire E, Lu J, England R, Dull C, Thorne T (1999) Deafness and imbalance associated with inactivation of the secretory Na-K-2Cl cotransporter. Nat Genet 22:192-195

Dib C, Faure S, Fizames C, Samson D, Drouot N, Vignal A, Millasseau P, Marc S, Hazan J, Seboun E, Lathrop M, Gyapay G, Morissette J, Weissenbach J (1996) A comprehensive genetic map of the human genome based on 5,264 microsatellites. Nature 380:152-154

Grifa A, Wagner CA, D'Ambrosio L, Melchionda S, Bernardi F, Lopez-Bigas N, Rabionet R, Arbones M, Monica MD, Estivill X, Zelante L, Lang F, Gasparini P (1999) Mutations in GJB6 cause nonsyndromic autosomal dominant deafness at DFNA3 locus. Nat Genet 23:16-18

Kelsell DP, Dunlop J, Stevens HP, Lench NJ, Liang JN, Parry G, Mueller RF, Leigh IM (1997) Connexin 26 mutations in hereditary non-syndromic sensorineural deafness. Nature 387:80-83

Kubisch C, Schroeder BC, Friedrich T, Lutjohann B, E1-Amraoui A, Marlin S, Petit C, Jentsch TJ (1999) KCNQ4, a novel potassium channel expressed in sensory outer hair cells, is mutated in dominant deafness. Cell 96:437-446

Kurima K, Peters LM, Yang Y, Riazuddin S, Ahmed ZM, Naz S, Arnaud D, Drury S, Mo J, Makishima T, Ghosh M, Menon PS, Deshmukh D, Oddoux C, Ostrer H, Khan S, Riazuddin S, Deininger PL, Hampton LL, Sullivan SL, Battey JF Jr, Keats BJ, Wilcox ER, Friedman TB, Griffith AJ (2002) Dominant and recessive deafness caused by mutations of a novel gene, $T M C 1$, required for cochlear hair-cell function. Nat Genet 30:277-284

Lalwani AK, Goldstein JA, Kelley MJ, Luxford W, Castelein CM, Mhatre AN (2000) Human nonsyndromic hereditary deafness DFNA17 is due to a mutation in nonmuscle myosin MYH9. Am J Hum Genet 67: 1121-1128

Lathrop GM, Lalouel JM (1984) Easy calculations of lod scores and genetic risks on small computers. Am J Hum Genet 36:460465

Leon PE, Raventos H, Lynch E, Morrow J, King MC (1992) The gene for an inherited form of deafness maps to chromosome 5q31. Proc Natl Acad Sci U S A 89:5181-5184

Liu XZ, Walsh J, Tamagawa Y, Kitamura K, Nishizawa M, Steel KP, Brown SD (1997) Autosomal dominant non-syndromic deafness caused by a mutation in the myosin VIIA gene. Nat Genet 17:268269

Lynch ED, Lee MK, Morrow JE, Welcsh PL, Leon PE, King MC (1997) Nonsyndromic deafness DFNA1 associated with mutation of the human homolog of the Drosophila gene diaphanous. Science 278:1315-1318

McGuirt WT, Prasad SD, Griffith AJ, Kunst HP, Green GE, Shpargel KB, Runge C, Huybrechts C, Mueller RF, Lynch E, King MC, Brunner HG, Cremers CW, Takanosu M, Li SW, Arita M, Mayne R, Prockop DJ, Van Camp G, Smith RJ (1999) Mutations in COL11a2 cause non-syndromic hearing loss (DFNA13). Nat Genet 23:413419

Melchionda S, Ahituv N, Bisceglia L, Sobe T, Glaser F, Rabionet R, Arbones ML, Notarangelo A, Di Iorio E, Carella M, Zelante L, Estivill X, Avraham KB, Gasparini P (2001) MYO6, the human homologue of the gene responsible for deafness in Snell's waltzer mice, is mutated in autosomal dominant nonsyndromic hearing loss. Am J Hum Genet 69:635-640

Robertson NG, Lu L, Heller S, Merchant SN, Eavey RD, McKenna M, Nadol JB Jr, Miyamoto RT, Linthicum FH Jr, Lubianca Neto JF, Hudspeth AJ, Seidman CE, Morton CC, Seidman JG (1998) Muta- 
tions in a novel cochlear gene cause DFNA9, a human nonsyndromic deafness with vestibular dysfunction. Nat Genet 20:299-303

Vahava O, Morell R, Lynch ED, Weiss S, Kagan ME, Ahituv N, Morrow JE, Lee MK, Skvorak AB, Morton CC, Blumenfeld A, Frydman M, Friedman TB, King MC, Avraham KB (1998) Mutation in transcription factor POU4F3 associated with inherited progressive hearing loss in humans. Science 279:1950-1954

Van Laer L, Huizing EH, Verstreken M, van Zuijlen D, Wauters JG, Bossuyt PJ, Van de Heyning P, McGuirt WT, Smith RJ, Willems PJ, Legan PK, Richardson GP, Van Camp G (1998) Nonsyndromic hearing impairment is associated with a mutation in DFNA5. Nat Genet 20:194-197

Verhoeven K, Van Laer L, Kirschhofer K, Legan PK, Hughes DC, Schatteman I, Verstreken M, Van Hauwe P, Coucke P, Chen A, Smith RJ, Somers T, Offeciers FE, Van de Heyning P, Richardson GP, Wachtler F, Kimberling WJ, Willems PJ, Govaerts PJ, Van Camp G (1998) Mutations in the human alpha-tectorin gene cause autosomal dominant non-syndromic hearing impairment. Nat Genet 19:60-62
Wayne S, Robertson NG, DeClau F, Chen N, Verhoeven K, Prasad S, Tranebjarg L, Morton CC, Ryan AF, Van Camp G, Smith RJ (2001) Mutations in the transcriptional activator EYA4 cause late-onset deafness at the DFNA10 locus. Hum Mol Genet 10:195-200

Xia JH, Liu CY, Tang BS, Pan Q, Huang L, Dai HP, Zhang BR, Xie W, Hu DX, Zheng D, Shi XL, Wang DA, Xia K, Yu KP, Liao XD, Feng Y, Yang YF, Xiao JY, Xie DH, Huang JZ (1998) Mutations in the gene encoding gap junction protein beta-3 associated with autosomal dominant hearing impairment. Nat Genet 20:370-373

Xiao S, Yu C, Chou X, Yuan W, Wang Y, Bu L, Fu G, Qian M, Yang J, Shi Y, Hu L, Han B, Wang Z, Huang W, Liu J, Chen Z, Zhao G, Kong X (2001) Dentinogenesis imperfecta 1 with or without progressive hearing loss is associated with distinct mutations in DSPP. Nat Genet 27:201-204

Young TL, Ives E, Lynch E, Person R, Snook S, MacLaren L, Cator T, Griffin A, Fernandez B, Lee MK, King MC (2001) Non-syndromic progressive hearing loss DFNA38 is caused by heterozygous missense mutation in the Wolfram syndrome gene WFS1. Hum Mol Genet 10:2509-2514 